\title{
Konstruksi Identitas dan Relasi Interpersonal oleh 'Roleplayer' Artis K-Pop di Twitter
}

\author{
Nokia Putri Andika Lainsyamputty \\ Universitas Gadjah Mada \\ Alamat: Jalan Sosio Yustisia, No.1 Caturtunggal, Depok, Sleman, Yogyakarta 55281, Indonesia \\ e-mail: nokia.putri.a@mail.ugm.ac.id
}

\section{Construction of Identity and Interpersonal Relationships by K-Pop Artist Roleplayers on Twitter}

\begin{abstract}
Indonesia is a country with the highest development of the K-Pop target market in Southeast Asia. This also raises various participatory behaviors from fans. One form of participatory behavior is roleplaying, which is playing roles on social media using a K-Pop artist's identity. As roleplayers, they will present themselves as K-Pop artists and build relationships with other roleplayers. Twitter is the social media most commonly used by roleplayers because of its features that support identity presentation and personal communication with other people. Even though they use other people's identities, roleplayers will also build various interpersonal relationships with fellow roleplayers like in the real world, from friendships to romantic relationships. This study aims to explain how K-Pop artist roleplayers construct their identity and interpersonal relationships through Twitter. This research used symbolic interactionism theory as the guide. The research method used is qualitative, with research data obtained through questionnaires with open-ended questions and analyzed thematically. From the answers of 131 respondents, K-Pop artists' identity was the object that roleplayers were trying to present. They present it by providing factual information about the artist and forming a good self-image. The way they present the $K$-Pop artist's identity will affect their interactions with other roleplayers, which have several determining factors, namely similarities, trust, feedback, and the parasocial relationship with the used muse. This interaction will determine the formation of interpersonal relationships, including friendship and romantic relationships. There are different types of real-world roleplayer information given between their friends and lovers.
\end{abstract}

Keyword : Identity; symbolic interactionism; interpersonal relations; roleplayer

ABSTRAK

Indonesia merupakan negara dengan perkembangan target pasar K-Pop tertinggi di Asia Tenggara. Ini pun memunculkan berbagai perilaku partisipatoris dari penggemarnya. Salah satu bentuk perilaku partisipatoris itu adalah roleplaying, yaitu bermain peran di media sosial dengan menggunakan identitas dari artis K-Pop. Sebagai roleplayer, mereka akan mempresentasikan diri menjadi artis K-Pop dan menjalin hubungan dengan roleplayer lain. Twitter merupakan media sosial yang paling umum digunakan oleh para roleplayer karena fiturnya yang mendukung presentasi identitas maupun komunikasi secara personal dengan orang lain. Meskipun menggunakan identitas orang lain, para roleplayer juga akan dapat membangun berbagai relasi interpersonal dengan sesama roleplayer layaknya di dunia nyata, mulai dari persahabatan hingga hubungan romantis. Penelitian ini bertujuan untuk menjelaskan bagaimana para roleplayer artis K-Pop mengonstruksi identitas dan hubungan interpersonal mereka melalui media sosial Twitter. Penelitian ini menggunakan teori interaksionisme simbolik sebagai pedoman. Metode penelitian yang digunakan adalah kualitatif, dengan data penelitian yang didapatkan melalui kuisioner dengan pertanyaan terbuka dan dianalisis secara tematik. Dari jawaban 131 responden, ditemukan bahwa identitas dari artis K-Pop adalah objek yang berusaha dipresentasikan oleh para roleplayer. Mereka mempresentasikannya dengan memberikan informasi faktual tentang artis terkait dan membentuk citra diri yang baik. Cara mereka mempresentasikan identitas dari artis K-Pop tersebut akan memengaruhi interaksi mereka dengan roleplayer lain, yang memiliki beberapa faktor penentu yaitu kesamaan, kepercayaan, umpan balik, dan hubungan parasosial dengan muse yang digunakan. Interaksi ini akan menentukan pembentukan hubungan interpersonal, termasuk di dalamnya adalah pertemanan dan hubungan romantis. Terdapat perbedaan jenis informasi dunia nyata roleplayer yang diberikan kepada teman dan pacar.

Kata kunci : Identitas; interaksionisme simbolik; relasi interpersonal; roleplayer 


\section{LATAR BELAKANG}

Media digital telah mempertipis batasan antara ruang-ruang global. Konsumen media yang dulunya merupakan pihak yang pasif, kini dapat menjadi pihak yang aktif karena interaksi antara konsumen dan produsen semakin dimungkinkan dengan adanya aturan baru. Istilah budaya partisipatoris pun muncul untuk menjelaskan bagaimana konsumen dari media kini berpartisipasi dalam budaya yang sedang berkembang (Jenkins, 2006). Salah satu golongan konsumen yang sangat berpartisipasi aktif dalam pembentukan budaya di media digital adalah penggemar. Penggemar merupakan individu yang terobsesi dengan bintang media, aktor, selebriti, atau acara TV, dan mereka menciptakan budaya partisipatif melalui interpretasi dan kreasi konten media dari objek kegemaran mereka tersebut (Yan \& Yang, 2020). Lingkungan digital baru juga meningkatkan kecepatan komunikasi penggemar. Saat komunitas semakin besar dan waktu reaksi semakin pendek, fandom menjadi jauh lebih efektif sebagai platform aktivisme konsumen (Jenkins, 2006). Fandom merupakan sekelompok orang yang terhubung melalui minat yang sama terhadap sebuah objek (Thorne \& Bruner, 2006). Ketika penggemar menjadi audiens yang aktif dan interaktif, mereka bisa secara kreatif menghasilkan sejumlah teks berdasarkan idola yang mereka sukai, membuat komunitas penggemar virtual dan otonom yang berasal dari 'bawah', yang berada di luar industri namun berbagi fitur dengan mereka (Jeewa \& Wade, 2015). Budaya partisipatif ini juga membuat penggemar menunjukkan aspek adaptif dan positif, dengan menjadi pembuat konten bersama dengan persona media dan ingin menjalin hubungan dengan cara yang kreatif (Stever, 2017).

Korea Selatan merupakan negara di kawasan Asia Timur yang berhasil mewujudkan soft-power untuk memperkuat posisi mereka di antara pemain global. Hal ini mereka lakukan melalui penyebaran budaya populer mereka (Korean Pop atau K-Pop) ke seluruh dunia, yang disebut dengan hallyu wave. Istilah ini dimunculkan pertama kali oleh jurnalis asal Tiongkok pada akhir dekade 1990-an (Kim, 2015). Di kawasan Asia Tenggara, Indonesia adalah negara dengan target pasar terbesar untuk penyebaran K-Pop (Jung, Lee, \& Lee, 2017). Jumlah penggemar idola K-Pop yang begitu banyak di Indonesia menyiratkan sebuah potensi besar bagi industri musik dan hiburan Korea. Ketika para idola K-Pop menyusun daftar negara yang dikunjungi, Indonesia pun hampir selalu masuk ke dalam daftar (Pramadya \& Oktaviani, 2016). Daya tarik universal dari K-Pop juga menjadikannya sebagai budaya populer yang diterima oleh berbagai belahan dunia-seperti yang disebut oleh Lie (2012)-mulai dari umat Katolik Peru hingga umat muslim Indonesia.

Secara umum, K-pop menaungi banyak fandom, baik yang berasal dari kelompok musik (boy group dan girl group), penyanyi solo, hingga aktor dan aktris. Keterlibatan penggemar K-Pop yang berasal dari luar Korea dapat menjadi sarana untuk mendapatkan teman baru dan bergaul dengan teman sebaya (Bland, 2019). Ditambah dengan fakta bahwa penggunaan media sosial yang semakin marak akibat mudahnya akses terhadap teknologi komunikasi saat ini telah mengubah kecepatan dan tingkat interaksi antara produsen dan konsumen (Guschwan, 2012). Melalui media sosial, para idola K-pop bisa mendistribusikan konten mengenai kehidupan pribadi mereka kepada para penggemar. Dari sisi penggemar, hal ini membuat mereka memiliki rasa seolah-olah mengenal idola mereka di dunia nyata (Tantra, 2020). Penggemar pun bisa berinteraksi dengan idola kesukaan mereka melalui perantara media sosial. Terdapat beberapa jenis perilaku partisipatoris yang kemudian muncul dari penggemar idola K-Pop, salah satunya adalah roleplay.

Roleplay dalam konteks fandom mengacu pada penggemar yang bertindak seolah-olah mereka adalah karakter lain dan bermain dengan karakteristik yang menentukan karakter tersebut. Mereka bisa menjadi satu atau lebih persona sekaligus. Penggemar tersebut akan memasukkan aspek kepribadian mereka sendiri ke dalam karakter yang mereka perankan untuk menulis ulang narasi mengenai karakter tersebut (Booth, 2010). Dalam dunia fandom, memerankan selebritis tidak hanya dapat dilakukan dalam aksi panggung teatrikal, tetapi juga dilakukan di dunia cyber, yaitu melalui akun situs jejaring sosial (Nugraha, 2020). Dengan maraknya media sosial, penggemar budaya populer yang tergabung dalam fandom akan lebih mudah untuk beralih ke platform media baru untuk bersosialisasi dan berinteraksi satu sama lain (Jeewa \& Wade, 2015). McClellan (2013) menyatakan bahwa kesetiaan dan investasi (emosional, waktu, pikiran) dari penggemar terhadap dunia yang melingkupi karakter yang mereka perankan, adalah karakteristik yang menempatkan narasi dari roleplayer di media sosial ke dalam RPG (Role Playing Games) dibandingkan genre fan-fiction (fiksi penggemar). Fiksi penggemar memiliki kebebasan pembangunan dunia virtual yang sama, tetapi tidak memiliki interaktivitas seperti yang ada pada game roleplay (McDonald, 2017).

Fandom K-Pop pun tidak luput dari salah satu bentuk budaya partisipatoris ini. Dengan interaksi tanpa naskah, pemain roleplay akan mempelajari karakter dari artis K-Pop yang mereka perankan, mulai dari sifat, tindakan, hingga cara berpikir. Proses ini menjadikan roleplay sebagai salah satu cara untuk menyalurkan kecintaan penggemar pada idola mereka (Fatmawati \& Ali, 2017). Artis yang diperankan oleh seorang pemain roleplay disebut sebagai muse atau face-claim (FC), sementara pemain roleplay itu sendiri disebut sebagai mun (singkatan dari mundane) (Pratiwi \& Putra, 2018; Jeewa \& Wade, 2015). Twitter merupakan salah satu media 
sosial yang banyak digunakan oleh para penggemar ini untuk melakukan kegiatan roleplay. Penggemar akan memainkan peran sebagai karakter yang mereka idolakan dan menggunakan identitas karakter tersebut sebagai identitasnya di Twitter (Kurniawati, 2015). Twitter juga menjadi media sosial yang tepat untuk mengobservasi reaksi dari penggemar K-Pop karena mereka secara aktif bersosialisasi dengan komunitas mereka di situs tersebut (Abd-Rahim, 2019). Ini juga didasari oleh struktur Twitter yang memungkinkan untuk terjadinya penyebaran percakapan ke seluruh jaringan aktor yang saling berhubungan tanpa membatasi percakapan dalam ruang atau kelompok. Banyak orang dapat berbicara tentang topik tertentu sekaligus, sehingga orang lain merasa dikelilingi oleh percakapan, meskipun bukan kontributor aktif (Boyd, Golder, \& Lotan, 2010). Update dari kegiatan artis yang dilakukan roleplayer akan memanfaatkan fitur-fitur di Twitter, seperti mengunggah media (foto, video, gif, atau lagu), menggunakan tagar, me-retweet atau like, hingga membuat utas. Sementara identitas dari muse akan ditampilkan para roleplayer melalui display name, foto profil, header, dan deskripsi singkat mengenai muse mereka di bio profil Twitter mereka. Sesama akun roleplayer pun dapat berinteraksi dan menjalin hubungan dengan menggunakan fitur-fitur dari Twitter tersebut.

Dalam salah satu literatur terawal tentang roleplay di dalam dunia fandom, Booth (2010) menyatakan bahwa formasi identitas pada dunia roleplay dapat mengalami ketegangan. Penggemar memberlakukan peran identitas ini bukan dengan melihat karakter seolah-olah nyata, tetapi dengan menghuninya dan memerankannya. Penggemar ini menegaskan tidak hanya kontrol atas karakter, tetapi juga habitatnya. Perbedaan antara bagaimana individu ingin mencitrakan artis yang mereka perankan versus bagaimana fandom membentuk harapan komunal tentang citra artis tersebut pun berkemungkinan terjadi (Booth, 2010)

Terdapat beberapa penelitian dan literatur mengenai roleplay dalam dunia fandom, khususnya fandom KPop, namun jumlahnya belum banyak. Penelitian ini berkisar pada tema-tema mengenai identitas dan juga interaksi sosial pada roleplayer artis K-Pop. Kurniawati (2015) dalam penelitiannya mengenai produksi dan penerimaan pesan pada roleplayer menemukan bahwa roleplayer akan membentuk identitas mereka melalui fitur yang terdapat di Twitter menggunakan identitas artis yang mereka perankan. Identitas ini akan diperkuat melalui pengkombinasian kehidupan artis K-Pop yang sebenarnya dengan imajinasi mereka yang disajikan dalam bentuk Tweet. Penelitian lainnya mengenai identitas roleplayer juga dilakukan oleh Nugraha (2020), yang menemukan empat proses konstruksi identitas roleplayer di Twitter. Sementara Fatmawati \& Ali (2017) melakukan penelitian mengenai motif roleplayer dalam berinteraksi sosial dan menemukan bahwa ada empat motivasi interaksi sosial menurut Max Weber yang dapat diaplikasikan ke dalam dunia roleplay. Berfokus pada hubungan romantis oleh sesama roleplayer, Pratiwi \& Putra (2018) menemukan bahwa motif ingin tahu, motif cinta, dan motif harga diri adalah motif sosiogenesis yang melandasi roleplayer untuk menjalin hubungan romantis.

Penggemar sebagai pondasi dari fandom, dinyatakan oleh Jenkins (Jenkins, 2006) adalah pengadopsi awal dari teknologi digital. Perkembangan teknologi dari tahun ke tahun telah mengubah pola komunikasi individu dan kelompok, hingga budaya partisipatori semakin kentara ditemukan. Fungsi yang awalnya dimonopoli oleh segelintir institusi hierarkis seperti korporasi kini dapat diproduksi oleh penggemar yang kian aktif (DeMeo, 2016). Roleplay dalam fandom K-Pop merupakan bagian dari budaya partisipatoris karena adanya penyerapan, pengolahan, dan produksi narasi tertentu oleh penggemar terhadap artis K-Pop yang mereka idolakan. Interaksi dinamis yang tercipta diantara sesama pemain roleplay hingga mereka mampu membuat sebuah komunitas sendiri yang unik, juga menunjukkan bahwa saat ini, budaya partisipatoris yang difasilitasi oleh media sosial telah mencapai tahapan yang lebih lanjut. Ini juga diperkuat dengan semakin berkembangnya hallyu wave yang melanda Indonesia, membuat ukuran fandom K-Pop sendiri semakin besar dari waktu ke waktu. Namun demikian, penelitian mengenai roleplay sebagai salah satu bentuk budaya partisipatoris, terkhususnya di Indonesia, belum menjadi sebuah topik yang sering ditemukan di dalam kajian akademis. Populasi dari para pemainnya meskipun banyak, masih cenderung tersembunyi. Penelitian ini bertujuan untuk memberikan penjelasan yang komprehensif mengenai pembangunan identitas dan relasi interpersonal di dalam dunia roleplay fandom K-Pop, sekaligus menjembatani kekurangan-kekurangan dari penelitian sebelumnya mengenai roleplay dalam fandom K-Pop. Objek dari penelitian ini adalah roleplayer yang menggunakan muse artis K-Pop di media sosial Twitter karena pesatnya perkembangan hallyu wave di Indonesia saat ini. Twitter adalah media sosial paling umum yang digunakan oleh para roleplayer untuk bermain peran karena sifat microbloggingnya yang memungkinkan konten buatan pengguna dipublikasikan secara online di domain publik dari akun mereka sendiri. Sifatnya yang mudah digunakan oleh masyarakat umum memungkinkan terciptanya banyak komunitas penggemar transnasional raksasa yang hadir sepanjang waktu (Jeewa \& Wade, 2015), dan memudahkan para roleplayer untuk mengkonstruksi identitas sekaligus menjalin hubungan interpersonal. 


\section{METODE}

Data dari penelitian ini didapatkan dengan menyebarkan kuisioner pertanyaan terbuka melalui media sosial Twitter, dengan hasil data yang didapatkan berupa data kuantitatif dan data kualitatif. Kuisioner dengan pertanyaan terbuka adalah pertanyaan yang opsi tanggapannya tidak disediakan. Pertanyaan-pertanyaan ini memungkinkan peserta untuk menjawab dengan kalimat mereka sendiri. Metode ini berguna untuk menyelidiki topik baru atau yang belum banyak dijelajah, dan menawarkan kesempatan untuk mempelajari informasi yang tidak terduga (Sue \& Ritter, 2007). Metode ini sejalan dengan konsep interaksionisme simbolik yang bertujuan untuk mengungkap proses konstruksi makna. Makna yang diungkap merupakan hasil dari pengalaman yang subjektif, sehingga pertanyaan yang tidak dibatasi jawabannya akan memberikan gambaran kepada peneliti mengenai bagaimana responden mengkonstruksi realitas dan makna tersebut (Hanley, 1994; Colburn, 2000). Penggunaan kuisioner secara daring juga dilakukan atas pertimbangan target responden yang diharapkan. Kuisioner ini meliputi pertanyaan mengenai identitas roleplayer di dunia nyata serta pendapat dan persepsi mereka terhadap identitas dan hubungan intepersonal di dunia roleplay. Adapun kriteria dari partisipan dalam penelitian ini adalah individu yang bermain roleplay di Twitter dengan menggunakan artis K-pop sebagai musenya. Maka, target responden diekspektasikan memiliki akses ke Internet, khususnya Twitter yang menjadi platform utama dalam permainan roleplay. Dalam penelitian ini, meskipun dibantu oleh kuisioner, namun peneliti sendiri tetap menjadi instrumen utama dalam penerjemahan dan analisis data. Adapun data kuantitatif yang didapatkan dari kuisioner penelitian merupakan data demografis dari responden serta pertanyaan umum mengenai roleplayer. Sementara, pertanyaan mendalam mengenai konstruksi identitas dan hubungan interpersonal di dunia roleplayer menghasilkan data kualitatif yang kemudian dianalisis lebih lanjut menggunakan analisis tematik.

Analisis tematik adalah metode untuk mengidentifikasi, menganalisis, dan melaporkan pola atau tema) dalam data. Teori memiliki posisi yang jelas dalam analisis ini, karena kerangka teoritis akan membawa sejumlah asumsi tentang sifat data, apa yang mereka wakili dalam istilah 'dunia', 'realitas', dan sebagainya (Braun \& Clarke, 2006). Penelitian ini menyajikan tema-tema yang muncul dari responden dengan topik terkait, di mana topik mengenai roleplayer artis K-Pop di Twitter belum kaya akan hasil penelitian. Proses pengumpulan data dilakukan selama satu minggu, yaitu dari 8 Januari 2021 hingga 17 Januari 2021, dan berhasil mengumpulkan 131 tanggapan.

\section{HASIL DAN DISKUSI}

\section{Interaksionisme Simbolik dalam Roleplay}

Penelitian ini menggunakan teori interaksionisme simbolik sebagai penuntun. Interaksionisme simbolik membahas bagaimana masyarakat diciptakan dan dipelihara melalui interaksi berulang antar individu (Griffin, 2012). Herbert Blumer (1986) merumuskan hasil pemikiran George H. Mead ke dalam sebuah teori interaksionisme simbolik yang memiliki tiga premis utama. Pertama, makna dari sebuah objek akan selalu dinamis karena adanya definisi yang dibuat oleh manusia terhadap objek tersebut. Premis kedua, makna dari objek-objek tersebut terbentuk dari interaksi sosial yang dilakukan individu dengan individu lain. Dengan demikian, interaksionisme simbolik melihat makna sebagai produk sosial, sebagai kreasi yang terbentuk di dalam dan melalui aktivitas pendefinisian manusia ketika mereka berinteraksi. Premis ketiga dari teori ini adalah makna terus dibuat dan diciptakan kembali melalui proses penafsiran yang terjadi akibat interaksi dengan orang lain. Penafsiran ini dimulai individu melalui interaksi dengan dirinya sendiri terlebih dahulu. Individu akan memilih, memeriksa, menangguhkan, menyusun kembali, dan mengubah makna dalam situasi di mana dia ditempatkan dan arah tindakannya.

Teori interaksionisme simbolik kemudian melahirkan konsep mengenai self (diri) karena adanya komitmen emosional dan psikis yang terjadi antar individu. Orang-orang di luar individu akan membantu individu tersebut mempelajari tentang perbedaan dan kemiripan dengan orang lain dan membantu untuk mengetahui siapa mereka sebagai pribadi. Diri adalah objek sosial yang penting, didefinisikan dan dipahami dalam istilah yang dikembangkan dari waktu ke waktu melalui interaksi dengan orang lain (Littlejohn, Foss, \& Oetzel, 2016; Alruwaili, 2017). Melalui proses pengambilan peran, individu melekatkan makna pada simbol, dan kemudian bertindak sesuai dengan interpretasi subjektif mereka terhadap simbol tersebut. Mereka juga membayangkan tanggapan orang lain dan mempertimbangkan tanggapan itu sebelum bertindak (Wong, 2012). Di satu sisi, identitas adalah produk dari biografi pribadi seseorang yang unik. Namun identitas juga bervariasi sesuai dengan siapa seseorang hidup saat itu, situasi sosial yang melingkupi, dan motivasi yang dimiliki individu saat itu (Buckingham, 2008). Orang tidak dilahirkan dengan konsep diri, melainkan mempelajarinya melalui interaksi (West \& Turner, 2010). 
Individu dapat membuat klaim tentang identitas mereka (misalnya, dengan menyatakan afiliasi dengan anggota lain dari suatu kelompok), tetapi klaim tersebut perlu diakui oleh orang lain (Buckingham, 2008). Manifestasi dari dukungan konsep diri yang dirasakan pun akan mengarah pada ketertarikan antarpribadi, yang menjadi dasar dari pembentukan hubungan interpersonal. Perbedaan jenis dan intensitas dukungan konsep diri timbal balik mengarah pada jenis hubungan interpersonal yang berbeda; misalnya, antara dengan teman atau dengan pasangan; dan intensitas yang berbeda dari hubungan tertentu, misalnya, seseorang mungkin memiliki teman biasa, teman baik, dan sahabat (Cushman \& Cahn, 1985). Identitas individu dan bagaimana mereka berusaha mengambil bagian dari kelompok sebagian besar bergantung pada hubungan yang dibangun dengan individu lain dan bentuk komunikasi yang diciptakan agar hubungan ini terintegrasi dan bermakna (de Lopes, 2012). Cara manusia berinteraksi manusia akan berubah dari waktu ke waktu, terutama pada era modern seperti saat ini. Ketika teori interaksionisme simbolik dibawa ke ranah media sosial, pengguna media sosial yang menjadi sebuah komunitas global membentuk individualitas dan menawarkan ruang yang besar bagi mereka untuk membangun korelasi (Madni, 2014). Kita semua membuat makna subjektif dan asosiasi pribadi saat kita mengonsumsi media, tetapi proses pembuatan makna menjadi signifikan secara budaya ketika makna tersebut dibagikan oleh kelompok yang lebih besar. (Jenkins, 2012).

Budaya partisipatif muncul lebih dahulu dari perkembangan digital, tetapi munculnya jaringan digital mengubah cara budaya partisipatif beroperasi. Orang-orang yang mungkin tidak pernah bertemu satu sama lain dapat memiliki pertukaran yang bermakna, dengan bentuk ekspresi yang mengalir dengan cepat dan luas (Jenkins, 2012). Dengan semakin banyaknya orang yang terhubung satu sama lain melalui Internet dan media sosial, ide, pengetahuan, dan kreasi dapat mengalir tanpa hambatan. Terlibat dalam partisipasi pun menjadi lebih mudah dari sebelumnya. Seperti yang dinyatakan sebelumnya, salah satu aspek budaya partisipatif adalah gagasan bahwa anggotanya merasakan rasa memiliki, percaya bahwa kontribusi mereka penting dan bahwa mereka adalah bagian berharga dari komunitas tempat mereka berasal (DeMeo, 2016).

Dasar dari roleplay sendiri adalah pengadopsian identitas orang lain; dalam hal ini, adalah identitas artis yang diperankan seperti nama, usia, atribut fisik dan juga psikis. Para pemain roleplay pun akan mengolah dan menginterpretasi identitas dari artis tersebut untuk kemudian memproduksinya kembali dalam bentuk media seperti teks, gambar, atau video. Namun, meskipun terdapat dua roleplayer yang menggunakan identitas artis yang sama, bagaimana cara dua individu melekatkan makna pada identitas artis yang sama bisa jadi berbeda. Hal ini menandakan bahwa keberagaman sifat yang terjadi tergantung kepada subjektifitas interpretasi masingmasing individu. Apalagi di dalam konteks media sosial, pengolahan makna kurang berfokus pada objek nyata, melainkan lebih pada elemen-elemen abstrak yang dapat menciptakan makna (Markham \& Lindgren, 2014), sehingga perbedaan yang signifikan mungkin terjadi.

Layaknya di dunia nyata, sesama roleplayer pun dapat membentuk berbagai macam relasi interpersonal seperti pertemanan dan hubungan romantis. Hubungan yang terbentuk antara roleplayer ini tidak harus mengimitasi hubungan sang artis di dunia nyata. Misal, di dunia nyata, artis $X$ tidak mengenal artis $Y$. Namun pada dunia roleplay, roleplayer artis $\mathrm{X}$ dapat berteman atau berpacaran dengan roleplayer artis $\mathrm{Y}$. Seorang roleplayer juga dapat mengubah orientasi seksual muse mereka (Jeewa \& Wade, 2015) dengan menjalin hubungan heteroseksual atau homoseksual. Hal ini difasilitasi oleh adanya fitur-fitur di Twitter seperti direct message atau reply dan quote tweet yang memberi akses pada roleplayer untuk berbicara dan berinteraksi baik secara publik maupun privat (Fatmawati \& Ali, 2017). Munculnya autobase khusus roleplayer dengan pengikut yang masif juga menjadi penanda bahwa terdapat kebutuhan bagi para roleplayer untuk berinteraksi dan menjalin hubungan dengan sesama pemain. Autobase merupakan akun Twitter yang memfasilitasi pengguna untuk mengirimkan sebuah tweet secara otomatis dalam interval waktu tertentu (Lihat Gambar 1).

Karena terdapat perbedaan dalam pemberian makna pada identitas artis yang mereka perankan, hal ini akan mengarahkan para pemain roleplay untuk mengalami proses interaksi dan rekonstruksi makna yang juga berbeda. Makna yang melekat dan tanggapan individu terhadap makna tersebut saling terkait erat selama interaksi sosial dan tidak terisolasi satu sama lain (Chen, Davison, \& Ou, 2020). Sebagai hasilnya, mereka juga akan memiliki hubungan interpersonal yang unik dengan roleplayer lain. 

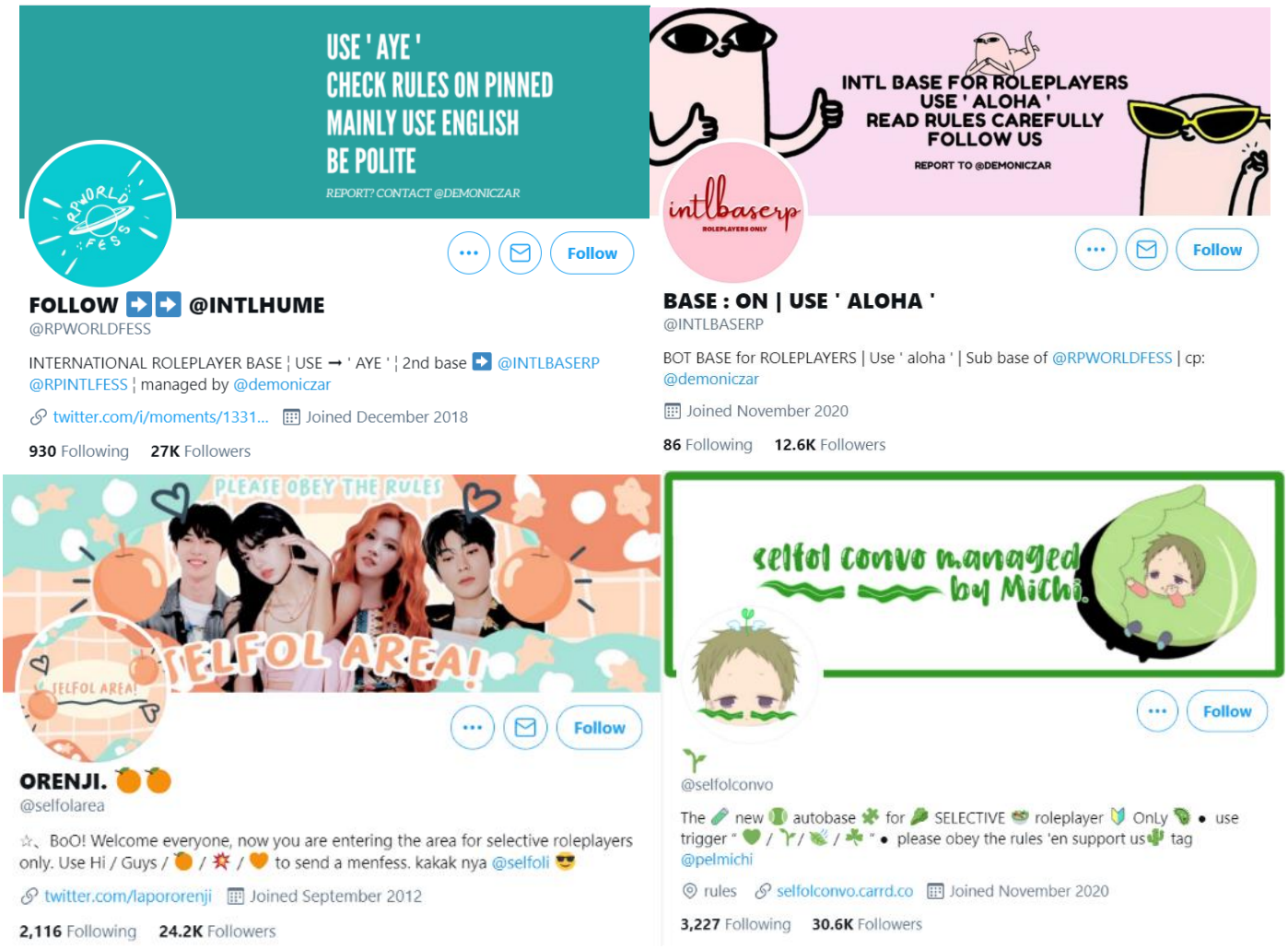

Gambar 1. Contoh Autobase Khusus Roleplayer di Twitter.

\section{Demografis}

Dari 131 responden yang mengisi kuisioner ini, perempuan mendominasi dengan jumlah 86,3\% atau 113 orang responden. 60 orang menyatakan bahwa terdapat perbedaan antara gender mun dan muse mereka. Usia dewasa awal, yaitu antara 18 hingga 24 tahun, merupakan rentang usia yang mendominasi pada responden. Namun demikian, terdapat 23 responden yang masih berusia di bawah 18 tahun dan 6 orang responden yang berusia di atas 24 tahun. Perbedaan usia antara pemain roleplay dengan artis yang mereka perankan lebih besar persentasenya dibandingkan dengan perbedaan gender, dengan $87,8 \%$ responden melaporkan bahwa terdapat perbedaan usia antara mun dan muse mereka. Dari jumlah tersebut, 37 orang mun berusia lebih muda dari musenya, sementara 78 orang berusia lebih tua dari musenya. Waktu paling awal bagi para pemain untuk mulai masuk ke dalam dunia roleplay yang tercatat di kuisioner ini adalah tahun 2009. Meskipun demikian, tahun 2012 dan 2013 merupakan tahun yang paling banyak dijadikan para roleplayer untuk mulai masuk ke dalam dunia roleplay, dengan jumlah responden yang melaporkan sebanyak 46 orang. Dari segi jumlah akun roleplay yang dimiliki, frekuensi terbanyak jatuh kepada dua akun, dengan 40,5\% dari responden menyatakan bahwa mereka memiliki dua akun roleplay. Namun, juga ada sejumlah $16 \%$ responden yang memiliki lebih dari tiga akun roleplay. 57 responden menggunakan bahasa Inggris sebagai bahasa yang dominan di akun roleplay mereka, 48 responden menggunakan bahasa Indonesia dan Inggris secara seimbang, dan hanya 19 orang yang menjadikan bahasa Indonesia sebagai bahasa yang dominan. (Lihat Gambar 2 sampai Gambar 8) 


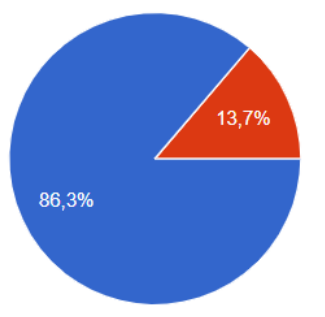

Gambar 2. Persentase Jenis Kelamin Mun

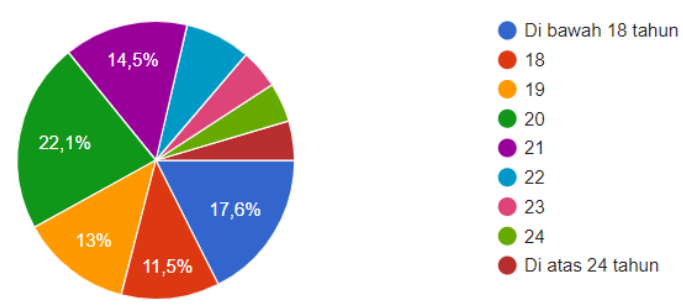

Gambar 3. Persentase Usia Asli Mun

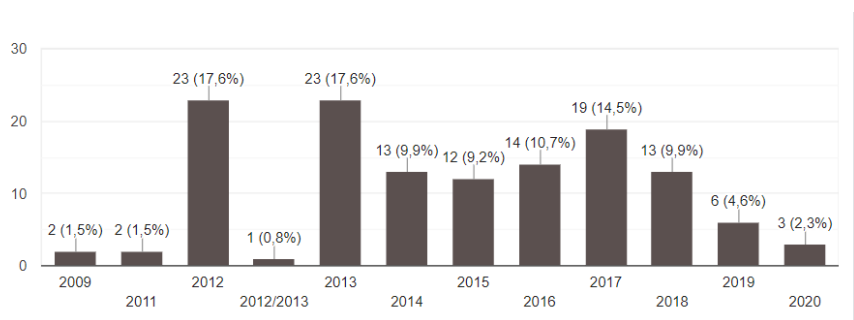

Gambar 4. Tahun awal bermain roleplayer

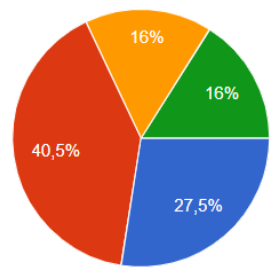

Gambar 5. Jumlah Akun Roleplay yang Dimiliki

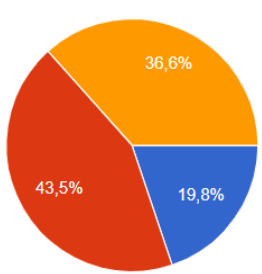

Gambar 6. Bahasa yang Digunakan di Akun Roleplay

Apakah gender dari artis yang kamu perankan di RP sama dengan gender aslimu? Jika kamu memiliki lebih dari 1 akun, pilih akun RP utama saja.

Apakah usia dari artis yang kamu perankan di RP sama dengan usia aslimu? Jika kamu memiliki lebih dari 1 akun, pilih akun RP utama saja. 131 tanggapan

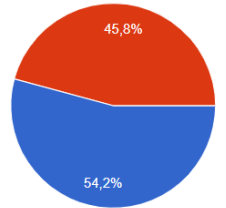

Gambar 7. Kesamaan Gender Mun dan Muse

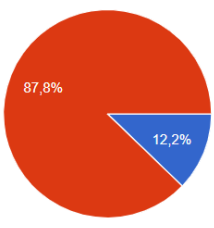

Gambar 8. Kesamaan Usia Mun dan Muse

\section{Identitas}

\section{Alasan Memerankan Artis K-Pop}

Sebagian besar dari responden menyatakan bahwa mereka memiliki kemiripan sifat dan karakter yang besar dengan artis yang sedang mereka perankan. Dari skala 1 hingga 10 dengan 1 untuk sifat yang bertolak belakang dan 10 untuk sifat yang sangat mirip, 33 orang menyatakan mereka ada di skala 7, 43 orang menyatakan mereka ada di skala 8, 21 orang menyatakan mereka ada di skala 9, dan 5 orang menyatakan mereka ada di skala 10. Skala terendah yang dilaporkan adalah pada skala 3 sebanyak 2 orang, yang berarti mereka tidak menganggap diri mereka memiliki kesamaan sifat yang signifikan dengan artis yang mereka perankan. 
Alasan para responden untuk memilih muse untuk mereka perankan di dunia roleplay dapat dibagi menjadi tiga kategori utama. Kategori pertama jawaban dilandasi oleh adanya hubungan parasosial antara responden dengan artis yang sedang mereka perankan. Hubungan parasosial didefinisikan sebagai hubungan sepihak yang dimiliki penggemar terhadap persona (artis, selebriti, performer). Hubungan ini akan dimulai oleh interaksi parasosial melalui konsumsi konten persona di media, yang pada level selanjutnya akan menumbuhkan rasa memahami, setia, dan menganggap persona terkait layaknya orang terdekat di dunia nyata. (Horton \& Wohl, 1956). Kebanyakkan dari para roleplayer merupakan penggemar dari muse yang mereka perankan. Jika artis tersebut jarang ada yang memerankan, maka para roleplayer menggunakan kesempatan ini untuk mempromosikan artis yang mereka gemari kepada audiens yang lebih luas. Selain itu, kemiripan karakter antara mun dengan muse mereka juga menjadi faktor yang penting dan membuat mereka nyaman dalam bermain peran. Oleh Perse \& Rubin (1989), kemiripan antara interaksi parasosial dan interaksi sosial dapat menyebabkan terjadinya peningkatan interaksi dan pengungkapan diri yang dirasakan penggemar melalui perantara media. Hal ini akan mengurangi ketidakpastian dan meningkatkan keintiman yang dirasakan penggemar dengan menyukai persona tersebut. Namun, ditemukan juga responden yang berusaha untuk mewujudkan proyeksi keinginan atau sifat yang tidak mereka miliki di dunia nyata melalui memerankan artis tersebut di dunia roleplay.

"Selain karena sifat-sifatnya yang di atas, Rosé BLACKPINK tuh jadi salah satu artis kpop yang saya sayang. Soalnya banyak hal-hal yang saya inginkan dan belum bisa tercapai ada di dirinya". (Septi, 22 tahun, perempuan)

"Suka sama cara pemikiran dia, pengen juga punya pemikiran yang luas kayak dia jadinya nge$R P$ in dia dan dari main RP juga berusaha untuk jawab dengan cara pikir dia. Reflektifnya juga dan bisa evaluasi apapun yang ada dalam dirinya dan juga yang ada di lingkungan". (S, 20 tahun, perempuan)

Kategori kedua jawaban lebih sarat akan elemen sosial atau relasional, dimana ditemukan bahwa beberapa pemain roleplay merasa lebih memungkinkan untuk menjalin banyak relasi jika muse yang mereka gunakan merupakan artis yang populer di kalangan K-Popers. Beberapa dari responden juga mengakui bahwa mereka memilih muse tertentu karena ingin dipasangkan dengan shipping yang diciptakan penggemar di dunia nyata.

"Karna awalnya dari ship aja, di 2018 tuh ada Halloweennya SM terus ngeliat charaku kek, "wah dia cakep banget, gemes", akhirnya pake chara dia biar bisa Jack-Rose an hahahah".

(Chané, 21 tahun, perempuan)

Pada kategori ketiga, alasan-alasan yang ditemui lebih cenderung kepada alasan praktis. Misalnya, keisengan memilih seorang muse yang berujung pada rasa nyaman untuk memerankan artis tersebut, ingin membangun suasana baru dengan karakter baru, foto artis yang tersedia dalam jumlah banyak di internet, serta paras artis yang rupawan.

"Awalnya karena saya gak ada akun terus kesisa akun artis tersebut, sayangnya suspend. Nah saya pindah, tapi saya pikir lebih baik jadi artis tersebut lagi, karena ada beberapa hal yang sama dari artis tersebut mulai dari MBTI, kepribadian, tingkah laku, dll... saya sama dengan dia saya memilih untuk memainkan peran sebagai artis itu". (AMA, di bawah 18 tahun, laki-laki)

\section{Cara Menyajikan Identitas}

Bermain roleplay melibatkan penggunaan identitas dari artis K-Pop yang dinarasikan berdasarkan imajinasi dan kemampuan dari pemain roleplay. Menjaga agar citra artis asli yang mereka perankan tidak ternodai menjadi suatu hal yang krusial. Terdapat kesamaan tema jawaban antara usaha yang dilakukan responden untuk memastikan bahwa mereka telah dengan baik memerankan muse mereka, dengan kriteria roleplayer yang baik menurut persepsi mereka. Jawaban tersebut dapat dikelompokkan menjadi dua tema utama, yaitu menyampaikan informasi faktual tentang artis, dan membangun citra diri sebagai pemain roleplay yang baik. Untuk dapat menyampaikan informasi faktual tentang artis, beberapa responden mengawalinya dengan mempelajari artis tersebut lebih dalam, baik melalui akun media sosial sang artis, mendengar lagu-lagu mereka, hingga menonton reality show dan penampilan mereka di panggung. Ketika mereka sudah memiliki informasi yang memadai mengenai artis tersebut, mereka akan melakukan update 
kegiatan muse mereka secara berkala di Twitter. Terdapat penyesuaian karakter yang dilakukan para mun dengan karakter muse mereka dalam melakukan update kegiatan sang artis, yang juga bertujuan untuk mempromosikan artis tersebut. Roleplayer yang mengetahui muse mereka dengan komprehensif dengan karakteristik yang mirip dengan artis aslinya dinilai responden sebagai salah satu ciri-ciri roleplayer yang baik.

"Mereka dapat mendalami karakternya sebagai artis dengan baik dari segi kepribadiannya dan juga mereka rajin update chara dengan kalimat yang bagus seolah mereka memang benar artis tersebut". (Pio, 20 tahun, perempuan)

Kategori pertama memiliki kaitan dengan kategori kedua, yaitu bagaimana para mun memasukkan unsur sikap asli mereka ke dalam muse yang mereka perankan demi membangun citra yang baik. Kesopanan tutur kata dan menghindari terlibat pertengkaran di ruang publik Twitter (lini masa) merupakan tema yang paling sering ditemukan, dilanjutkan dengan bagaimana para roleplayer membangun relasi yang baik dengan roleplayer lainnya. Tak jarang juga bagi pemain roleplay untuk meminta masukkan atau pendapat dari orang lain tentang cara mereka bermain peran.

"I'm extra careful with my words when tweeting and interacting with others, I never explicitly sweared or used bad words publicly, I always try to censor sensitive topics or add a content or trigger warning, I use tone tags sometimes, brackets when talking ooc, and since my muse is barely legal I never rted or talked about nsfw thingy at least not on timeline". (Far, 20 tahun, perempuan).

Pentingnya membangun citra yang baik di dunia roleplay ini didasari pada adanya asosiasi antara citra dari roleplayer dengan artis asli yang mereka perankan. Apa yang dilakukan oleh roleplayer dapat membuat mun menyukai artis asli yang menjadi muse dari pemain. Sebagian responden mengakui bahwa tak jarang mereka menyukai artis K-Pop di dunia nyata karena artis tersebut diperankan dengan baik oleh pemain roleplay lain. Selain itu, ketika seorang pemain roleplay menjalin hubungan romantis dengan pemain roleplay lainnya, terdapat kecenderungan dari mereka untuk ikut menyukai artis yang diperankan oleh pasangan mereka, di dunia nyata.

"Pernah. karena mereka memerankan musenya secara baik sekali sehingga saya (yang dulunya tidak menyukainya muse tersebut) jadi suka dengan musenya karena teringat mereka yang berperan sebagi muse tsb. saya jadi suka menyimpan foto artisnya karena saya jadi suka dgn mereka". (NA, 18 tahun, perempuan)

"Pernah. Alasannya karena muse tersebut pernah menjadi pacar saya di RP. Pacar saya kerap kali membagikan video performance muse yang ia gunakan, dan kerap memberi lagu yang dinyanyikan oleh muse yang ia gunakan pula. Karena hal-hal kecil tersebut saya jadi ingin lebih tahu informasi, musik, dan performance terkait muse yang ia perankan". (Keva, 20 tahun, perempuan).

Ini juga berlaku sebaliknya. Ketika roleplayer tidak memerankan artis tersebut dengan baik atau terlibat interaksi yang traumatis dengan roleplayer lain secara berulang, maka akan ada kecenderungan bagi para mun untuk menjadi tidak menyukai artis aslinya di dunia nyata.

"Karena aku ketemunya yg RPin mereka jelek terus. Dari suka sama grupnya, terus setelah liat banyak RPnya yg aneh (menurutku) aku jadi ga suka lagi sama grup/idolnya". (R, 18 tahun, perempuan)

"Karena banyak hal namun yang sering biasanya adalah ketika rp tersebut merebut atau menganggu hubungan romantis saya. Atau ketika dia menyakiti dengan sengaja sahabat saya. Dampaknya saya menjadi tidak ingin melihat mereka". (Ann, 20 tahun, perempuan)

\section{Hubungan Interpersonal}

\section{Proses Inisiasi Hubungan Interpersonal}

Memulai hubungan pertemanan di dunia roleplay dapat dilakukan melalui berbagai fitur yang hanya dapat dijumpai di dunia roleplay. Misalnya dengan penggunaan autobase, atau pembentukan komunitas 
berupa squad dan agensi yang biasanya memiliki kriteria (kesamaan usia, kesamaan agensi artis K-Pop di dunia nyata) dan kuota tertentu untuk menampung para roleplayer. Beberapa dari roleplayer juga tidak sungkan untuk mengikuti roleplayer lain yang mereka anggap menarik terlebih dahulu untuk memulai pertemanan (lihat Gambar 9).

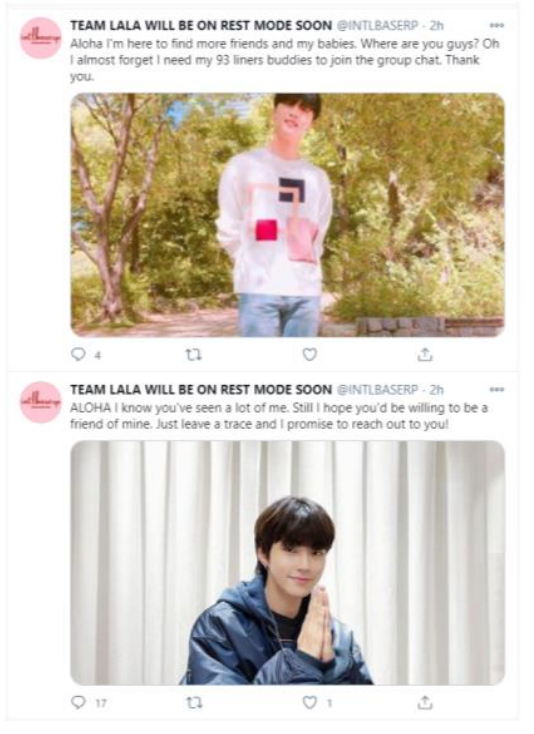

Gambar 9. Contoh Autobase untuk Roleplayer

Sementara untuk memulai hubungan romantis, terdapat juga akun yang ditujukan untuk mencari pasangan. Roleplayer yang menggunakan muse laki-laki akan mengirimkan kriteria pasangan mereka ke akun tersebut melalui direct message, lalu admin akan menyampaikannya ke lini masa secara anonim, dan roleplayer lain dapat membalas tweet terkait jika tertarik. Cara-cara ini berlaku untuk hubungan heteroseksual dan homoseksual (lihat Gambar 10).

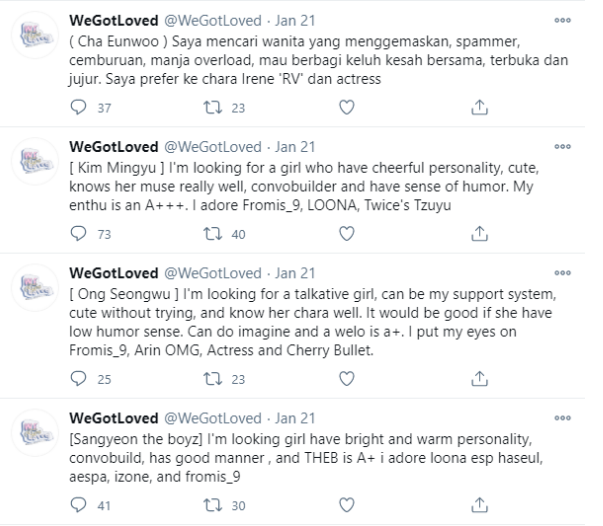

Gambar 10. Contoh Akun Mencari Pasangan untuk Roleplayer

Para roleplayer akan memiliki pertimbangan tertentu dalam menginisiasi hubungan pertemanan maupun hubungan romantis, yang secara umum, kedua jenis hubungan ini dilandasi oleh pertimbangan yang serupa. Jawaban dari responden dapat dikelompokkan menjadi tiga kategori utama. Pertama, citra atau presentasi diri oleh mun pada muse mereka. Roleplayer yang tidak suka mencari masalah, bertutur kata dengan baik, menciptakan narasi berupa ketikan yang rapi, dan memerankan artis sesuai dengan karakter artis aslinya adalah tipe roleplayer yang lebih disukai untuk menjalin hubungan pertemanan maupun romantis. Kedua, responden juga menilai kualitas interaksi yang dilakukan roleplayer sebagai salah satu tolok ukur yang penting. Ketika feedback yang mereka dapatkan tidak sesuai dengan ekspektasi dan tidak ada kemiripan sifat atau obrolan, mereka cenderung menghindari interaksi dengan roleplayer tersebut pada masa selanjutnya. Salah satu aspek yang membedakan antara hubungan pertemanan dengan hubungan romantis pada kategori interaksi ini adalah durasi membalas pesan. Ini penting bagi hubungan romantis, namun tidak terlalu signifikan pada hubungan pertemanan. 


\begin{abstract}
"Waktu. Rp adalah permainan dan yg saya butuh kan adalah interaksi dan afeksi. Bila dia tidak pernah online buat apa? Saya tau ini hanya game jd saya tidak menuntut online setiap hari. Minimal seminggu sekali kami bisa ngobrol dan makan bersama atau sekedar membicarakan hal hal di sekitar". (YV, 24 tahun, perempuan)
\end{abstract}

Kategori ketiga yang memengaruhi pertimbangan untuk menjalin hubungan interpersonal di dunia roleplay adalah pemilihan muse. Faktor ini mendapati jumlah hasil yang berbeda. Dalam hubungan pertemanan, 89 dari 131 responden menyatakan bahwa mereka tidak mempertimbangkan muse dari orang yang mereka tuju. Artinya, sebagian besar dari responden dapat berteman dengan roleplayer lain, terlepas dari siapapun muse yang mereka gunakan. Namun jawaban yang berbeda ditemukan pada hubungan romantis. Hanya 61 orang yang dapat menjalin hubungan dengan roleplayer lain tanpa memperhatikan muse dari roleplayer tersebut, dan 70 orang merasa perlu untuk mempertimbangkan muse dari calon pasangan mereka.

"Kalo aku gak kenal sama musenya, bakalan rada susah buat ngobrol. pertimbanganku biar ngobrol enak tuh aku tau line musenya, tanggal dan tahun debutnya, dan dari grup apa. tujuannya biar manggilnya jelas, apa harus manggil dengan honorifics atau gak usah, dan honorifics apa yang cocok". (Hersal, 19 tahun, perempuan)

"Karena saya tidak tahu banyak mengenai artist artist baru jadi saya cenderung pemilih". ( $\mathrm{T}$, di atas 24 tahun, perempuan)

Terdapat dua faktor unik yang menjadi pertimbangan para roleplayer dalam menjalin hubungan romantis, yang tidak ditemukan pada hubungan pertemanan. Beberapa dari mereka ingin mewujudkan fantasi dengan artis yang mereka sukai melalui menjalin hubungan romantis dengan roleplayer yang memakai identitas artis tersebut. Ada juga yang ingin mewujudkan shipping (pasangan) antara artis di dunia nyata yang dibentuk oleh penggemar dalam fandom. Shipping merupakan salah satu bentuk perilaku penggemar di mana mereka memasangkan artis atau karakter ke dalam sebuah hubungan romantis yang tidak benar-benar terjadi di dunia nyata, tanpa memandang gender dari pasangan tersebut (Kuo, PerezGarcia, Burke, Yamasaki, \& Le, 2020; Otolorin \& Spatichia, 2017). Temuan ini sejalan dengan konsep dari hubungan parasosial yang sebelumnya telah dijelaskan. Perwujudan fantasi pribadi maupun perwujudan shipping artis K-Pop yang dibuat penggemar merupakan salah satu fungsi dari hubungan parasosial. Khayalan penggemar tersebut merupakan perbuatan yang mereka lakukan untuk mengkompensasi hubungan sepihak dengan artis yang mereka sukai.

"Karena saya berfantasi menjalin hubungan dengan bias saya ketika mereka memakai muse bias saya". (Nadia, 21 tahun, perempuan)

"Iya, ya karena aku lebih suka pacaran dengan SHIP yang di buat fans? Called like BXB or GXG. I'm not into interested to relationship IRP crackship". (lel, 18 tahun, laki-laki)

Untuk responden yang tidak mempertimbangkan muse dari roleplayer ketika menjalin pertemanan atau hubungan romantis, terdapat dua alasan utama yang mereka kemukakan. Pertama, mereka lebih mementingkan sifat dan citra yang dibentuk oleh roleplayer. Jika roleplayer tersebut mereka anggap baik dan memenuhi ekspektasi mereka, maka mereka tidak akan sungkan menjalin hubungan tanpa melihat siapa artis yang diperankan. Kedua, berteman atau berpacaran dengan roleplayer yang memiliki muse kurang familiar, bagi beberapa responden, justru memberikan keuntungan yaitu bertambahnya wawasan mereka terhadap artis tersebut.

"Karena saya lebih mementingkan pada kepribadian dalam diri orang tersebut sih. Dulu juga pernah gak suka sama idola yang dipakai pacar saya, tapi malah jadi ngefans banget karena pembawaan karakternya". (KS, 19 tahun, perempuan)

"I think its good to make a friendship with so many muse. Semakin temenan sama muse lain akan semakin menambah pengetahuan juga". (Nathaya, 20 tahun, perempuan) 


\section{Proses Membuka Diri kepada Orang Terdekat}

79 responden berada pada rentang skala 7 hingga 10 untuk pertanyaan keterbukaan terhadap orangorang terdekat mereka di dunia roleplay. Secara umum, ini menandakan bahwa lebih dari separuh responden dapat membuka informasi terkait diri mereka kepada orang terdekat mereka di dunia roleplay. Para roleplayer mempersepsi bahwa beberapa karakter dari pihak lawan bicara akan membuat mereka mudah untuk membuka diri. Karakter pertama yaitu adanya kesamaan sifat ataupun obrolan, yang memudahkan terjadinya interaksi dan pembicaraan yang bermakna. Pihak lawan bicara yang dapat dipercaya pun menjadi karakter selanjutnya yang membuat para roleplayer dapat membuka diri mereka. Dari jawaban-jawaban responden, karakter dapat dipercaya ini dikelompokkan pada empat perilaku utama: memberi feedback yang sesuai, kesediaan pihak lawan bicara untuk menjadi orang pertama yang membuka diri, tidak menghakimi (non-judgemental), dan bisa menjaga rahasia.

Terdapat kemiripan antara jenis informasi mengenai diri pemain roleplayer di dunia nyata yang dapat dan tidak dapat diberitahukan kepada orang terdekat di dunia roleplayer. Kegiatan sehari-hari dan kesibukkan dari mun di dunia nyata adalah tema paling umum yang ditemukan untuk informasi yang menurut para roleplayer, dapat disampaikan kepada roleplayer lain. Selain itu, lingkungan sosial mun di dunia nyata juga dapat menjadi hal yang disampaikan atau dirahasiakan oleh para roleplayer, termasuk di dalamnya adalah masalah pertemanan atau keluarga dari mun. Namun untuk masalah keluarga, lebih banyak roleplayer yang menutupinya dari orang terdekat mereka. Kategori informasi lainnya adalah topik sensitif seperti orientasi seksual, kesehatan atau gangguan mental, dan masalah finansial. Identitas asli dari para roleplayer seperti nama, usia, domisili, wajah asli, agama, dan jenjang pendidikan atau pekerjaan menjadi kategori informasi yang lebih banyak dirahasiakan oleh para roleplayer, meskipun juga ada yang bersedia untuk memberitahukannya.

Terdapat 87 orang yang membedakan hal apa yang bisa mereka ceritakan kepada teman dan kepada pacar. Perbedaan informasi dan masalah di dunia nyata yang mereka ceritakan kepada teman dan pacar di dunia roleplay dilandasi pada beberapa faktor: tingkat kepercayaan, intensitas pembicaraan, respons pihak lain, dan penjagaan citra diri. Jika teman adalah pihak yang lebih sering berbicara dengan mereka atau lebih mereka percayai, maka responden akan lebih banyak melakukan self-disclosure kepada teman mereka-dan hal ini juga berlaku untuk pacar. Mereka juga membedakan topik apa yang lebih nyaman dibicarakan dengan teman atau dengan pacar, sehingga terdapat perbedaan jenis informasi yang disampaikan kepada kedua pihak tersebut. Dalam hubungan romantis, perbedaan jenis informasi yang disampaikan ini erat kaitannya dengan penjagaan citra diri oleh roleplayer. Mereka tidak ingin merusak fantasi pasangan mereka terhadap diri mereka dengan membatasi secara tegas antara urusan dunia nyata dengan urusan dunia roleplayer.

"Untuk pacar RP, biasanya saya memberikan informasi sesedikit mungkin, bahkan masalah umur. karena relasi pacar cenderung ingin tahu hal-hal tentang kita". (T, 21 tahun, perempuan)

"Ya karna beda aja gitu porsinya kalo temen deket bisa ngobrol apa aja tanpa harus mikir. kalo sama pacar yaa jaim dikit lah". (Dimi, 18 tahun, perempuan)

\section{Analisis Hasil Temuan}

Bermain roleplay merupakan salah satu bentuk budaya partisipatoris yang dapat ditemui pada fandom KPop. Menggunakan media sosial sebagai sarana bermain, dunia roleplay berisi pemain yang memerankan artis K-Pop dengan cara meminjam identitas artis tersebut. Kebanyakkan dari pemain merupakan penggemar dari artis K-Pop itu sendiri, sehingga hubungan parasosial dengan artis tersebut akan diwujudkan melalui pemilihan muse untuk bermain roleplay dan dalam membentuk hubungan interpersonal. Selain itu, alasan relasional untuk mendapatkan teman dan alasan praktis seperti keisengan adalah faktor lain yang memengaruhi pemilihan muse oleh roleplayer. Sebagai objek menurut interaksionisme simbolik, identitas artis K-Pop tersebut akan dipresentasikan para roleplayer melalui penyajian informasi faktual mengenai sang artis dan membentuk citra sebagai seorang roleplayer yang baik. Presentasi identitas artis K-Pop oleh para roleplayer ini kemudian akan memengaruhi bagaimana mereka saling berinteraksi untuk menginisiasi hubungan interpersonal. Interpretasi dari interaksi dan identitas tersebut kemudian akan menjadi penentu dalam pembentukan hubungan interpersonal seperti pertemanan atau hubungan romantis. Dalam hubungan interpersonal ini, terdapat elemen kepercayaan yang membuat para roleplayer tidak sungkan untuk membuka informasi terkait diri mereka di dunia nyata kepada orang yang mereka anggap dekat, baik itu teman maupun pacar.

Hubungan parasosial menjadi tema yang cukup mendominasi dalam jawaban-jawaban responden; dari alasan pemilihan muse, hingga pembentukan hubungan interpersonal dengan roleplayer lainnya. Dari skala 1 hingga 10, 102 orang menyatakan mereka ada di angka 7 hingga 10 untuk kemiripan sifat mereka dengan muse 
yang mereka perankan. 70 dari 131 responden menyatakan bahwa mereka mempertimbangkan muse roleplayer lain dalam menjalin hubungan romantis karena mereka ingin mewujudkan fantasi intimasi dengan muse roleplayer yang dituju. Karena hubungan antara persona dan penggemar adalah sepihak dan tidak dapat dikembangkan satu sama lain, hampir seluruh beban untuk menciptakan keintiman ditujukan pada persona. Jika ia berhasil memulai keintiman yang dapat dipercaya oleh penggemarnya, maka penggemar dapat membantu mempertahankannya melalui berbagai jenis dukungan yang dapat diberikan secara tidak langsung untuk menopang tindakannya (Horton \& Wohl, 1956). Jauhnya jarak sosial dan fisik antara artis dengan penggemar, di mana hal ini adalah aspek penting untuk menggambarkan tingkat keintiman di hubungan parasosial, dikompensasikan di masa modern dengan tersedianya interaksi pribadi melalui representasi yang dimediasi secara massal (Turner, 2013). Pada roleplayer, keinginan untuk menjadi dekat dengan artis kesukaan mereka dikompensasi melalui menggunakan identitas artis tersebut untuk bermain roleplay dan juga menjalin hubungan dengan roleplayer lain yang menggunakan identitas artis tersebut. Dinyatakan oleh Miller, Govil, McMurria, \& Maxwell (2001), penggemar yang membentuk hubungan parasosial dengan artis atau selebritis kesukaan mereka akan memiliki kemampuan spesial, yaitu kemampuan untuk mengonstruksi koneksi imajiner dengan artis tersebut, memenuhi fungsi pertemanan, atau membentuk ruang untuk memproyeksikan dan mengevaluasi skema yang memahami interaksi manusia. Maka ketika para penggemar melakukan kegiatan roleplay menggunakan identitas artis kesukaan mereka, ini juga termasuk salah satu bentuk pemenuhan fungsi dukungan, pertemanan, proyeksi identitas diri, dan keintiman dalam lingkup hubungan parasosial.

Membawa temuan mengenai identitas ini kepada konsep interaksionisme simbolik oleh Blumer (1986), dapat dikatakan bahwa objek yang berusaha dikonstruksi oleh para roleplayer merupakan identitas dari muse mereka. Identitas membentuk skema kognitif-afektif yang mengatur melalui mana individu menafsirkan pengalaman mereka dan sewaktu-waktu dapat berubah oleh pengalaman juga (Sneed \& Whitbourne, 2003). Interaksionisme simbolik memandang bahwa jika seseorang melabeli dirinya dengan cara tertentu, maka dia akan terlibat dalam tindakan yang mendefinisikan label tersebut. Individu pun akan melabeli dirinya sendiri, orang lain, situasi, dan perilaku yang terjadi dalam konteks identitas sosial, makna, dan definisi situasi (Blumer, 1986). Pemain roleplay melabeli diri mereka sebagai artis tertentu melalui pengadopsian identitas artis tersebut dan mengkonstruksinya kembali melalui media sosial, yaitu Twitter. Ini menunjukkan bahwa pemain roleplay secara subjektif telah menyematkan makna tertentu mengenai identitas artis yang mereka perankan, yang kemudian akan memengaruhi bagaimana cara mereka menyajikan identitas artis tersebut kepada orang lain melalui permainan roleplay.

Hubungan parasosial melibatkan ikatan sepihak antara roleplayer dengan muse mereka, di mana para roleplayer akan bersedia untuk mempelajari dan memahami identitas artis tersebut sebaik mungkin sebelum mereka mereproduksinya dalam bentuk narasi seperti update kegiatan atau cara berbicara yang semirip mungkin dengan skema kognitif-afektif artis aslinya. Begitu pula halnya ketika sesama roleplayer berinteraksi di Twitter. Identitas dari muse mereka akan terus menerus dikonstruksi melalui penafsiran interaksi mereka dengan roleplayer lain, sehingga akan muncul kesan tertentu mengenai identitas dari artis tersebut. Adanya penafsiran interaksi yang menghasilkan makna dari identitas artis tertentu ini juga memungkinkan terjadinya asosiasi yang baik atau buruk terhadap artis aslinya, karena bahkan diantara roleplayer yang memerankan artis yang sama, masih terdapat perbedaan karakteristik. Fenomena ini dapat dijelaskan melalui pengkondisian klasik oleh Pavlov, yaitu jenis respons dipelajari yang terjadi ketika objek netral (dalam hal ini, artis K-Pop) menghasilkan respons refleksif ketika dikaitkan dengan stimulus tertentu yang telah menghasilkan respons itu (dalam hal ini, baik buruknya interaksi dengan roleplayer tertentu) (Gazzaniga, Heatherton, Halpern, \& Heine, 2012). Respons emosional yang terkondisi dapat menyebabkan individu memiliki reaksi emosional terhadap orang, tempat, atau peristiwa tertentu, bahkan ketika mereka tidak mengetahui alasan reaksi mereka (Goldstein, 2011). Memiliki reaksi emosional yang menyebabkan rasa suka atau tidak suka terhadap artis K-Pop tertentu merupakan hasil dari asosiasi penafsiran pengalaman interaksi oleh roleplayer dengan artis yang bersangkutan.

Familiarity (keakraban atau pengetahuan terhadap artis tertentu) menjadi faktor utama yang membuat responden mempertimbangkan muse dalam berteman atau menjalin hubungan romantis. Akan lebih mudah bagi mereka untuk mengidentifikasi atau membentuk ekspektasi terhadap seorang roleplayer jika mereka telah mengenali muse yang dituju, begitupun sebaliknya. Ini sejalan dengan hasil studi dari Finkel, et al. (2015) yang menunjukkan bahwa keakraban cenderung meningkatkan ketertarikan ketika individu dapat dengan mudah mengintegrasikan informasi tambahan tentang orang yang menjadi sasaran dengan informasi yang mereka peroleh sebelumnya tentang dirinya.

Untuk menjalin hubungan interpersonal yang lebih dalam, para roleplayer juga melakukan self-disclosure yang didasari oleh beberapa prasyarat tertentu. Miripnya sifat dan obrolan antara kedua pihak menjadi salah satu alasan utama. Temuan ini sejalan dengan hipotesis persamaan (similarity hypothesis) yang menyatakan 
bahwa semakin mirip dua orang, semakin mereka cenderung menyukai satu sama lain. Kesamaan telah terbukti menjadi dasar untuk ketertarikan di banyak jenis situasi dan banyak jenis hubungan. Dibandingkan kesamaan yang terjadi secara objektif, kesamaan yang dipersepsi oleh kedua pihak secara subjektif menjadi penentu yang lebih efektif dalam sebuah hubungan (Baron \& Branscombe, 2012)

Karakter lainnya yang ditemukan dapat menjadi landasan konstruksi hubungan interpersonal sesama roleplayer adalah trustworthiness. Kepercayaan bekerja secara timbal balik, sehingga ketika seseorang mempercayai orang lain, mereka menjadi lebih cenderung berperilaku dengan cara yang dapat dipercaya dan sebagai balasannya mempercayai orang tersebut (Lewicki, Tomlinson, \& Gillespie, 2006). Selain itu, kemampuan untuk mendengarkan seseorang secara penuh perhatian dan tidak menghakimi akan membuat pencerita merasa dihormati dan dihargai oleh pendengar menumbuhkan rasa dihormati pada pencerita (Gilburt, Rose, \& Slade, 2008), yang juga akan memperkuat kepercayaan terhadap seseorang.

Dari perspektif interaksionisme simbolik, individu dipengaruhi oleh kekuatan sosial yang ada dan secara interaktif menggunakan simbol (seperti, bahasa, makna yang dijiwai) untuk mengembangkan pengertian tentang diri mereka sendiri, peran mereka, dan hubungan mereka dengan orang lain (Juhasz \& Bradford, 2016). Identitas artis K-pop yang digunakan roleplayer dan bagaimana cara mereka mempresentasikan identitas tersebut tersaji melalui fitur-fitur di Twitter, seperti profil, tweet, pesan personal, dan lainnya. Identitas yang tersaji di Twitter ini merupakan simbol yang dimaknai dan diinterpretasi oleh para roleplayer lain, yang akan memengaruhi bagaimana mereka berperilaku di dunia tersebut, termasuk di dalamnya adalah untuk menjalin hubungan interpersonal. Mengacu pada model pembentukan hubungan persahabatan dan romantis oleh Cushman, Valentinsen, \& Dietrich (dalam Cushman \& Cahn, 1985), hubungan akan dimulai ketika seseorang mengidentifikasi karakter yang diinginkan dari seseorang untuk membentuk sebuah hubungan. Pada dunia roleplay, jawaban dari responden dapat dikelompokkan menjadi tiga, yaitu muse yang digunakan, cara mempresentasikan identitas muse, dan cara berinteraksi dengan orang sekitar. Setelah itu, akan terjadi pendekatan, dan hubungan pun akan terbentuk ketika terjadi timbal balik yang setimpal. Sebagai bagian dari budaya partisipatoris dalam fandom K-Pop, hubungan interpersonal dengan artis K-Pop menjadi salah satu faktor yang melandasi para roleplayer dalam mengkonstruksi identitas dan menjalin hubungan dengan roleplayer lainnya.

Pertimbangan dalam membentuk hubungan interpersonal ini juga didukung oleh sifat media sosial yang terbuka dan kaya akan informasi dari identitas penggunanya. Selain itu, media sosial menyediakan banyak kesempatan bagi penggunanya untuk mempresentasikan diri melalui gambar, video, dan deskripsi diri. Penggunaan strategi pasif seperti observasi pun akan sering digunakan untuk membentuk kesan tentang orang yang menjadi sasaran, dengan tujuan untuk mengurangi ketidakpastian menggunakan cara yang lebih mudah dan cepat (Antheunis, Valkenburg, \& Peter, 2010). Dalam konteks dunia roleplay di Twitter, impresi dan identitas seorang roleplayer dapat diakses dengan mudah sehingga juga akan semakin mudah bagi roleplayer lain untuk menentukan reaksi mereka-apakah mereka ingin menjalin hubungan dengan orang tersebut atau tidak. Namun penggunaan strategi pasif dalam membentuk hubungan interpersonal di media sosial tidak akan mencukupi. Seseorang perlu melakukan strategi interaktif seperti bertanya hal-hal personal untuk memancing terjadinya pembukaan diri yang timbal balik (Walther, 2015). Twitter telah memfasilitasi terjadinya interaksi interaktif ini melalui fitur-fitur mereka, seperti direct message, reply tweet, quote tweet, dan sebagainya. Para roleplayer pun akan berinteraksi secara interaktif dengan roleplayer lainnya untuk memicu terjadinya self-disclosure dan pengembangan hubungan interpersonal.

Hasil dari penafsiran roleplayer terhadap interaksi yang mereka lakukan pada roleplayer lainnya akan menentukan kelanjutan hubungan interpersonal mereka. Mereka akan memilih orang-orang yang dapat mereka anggap dekat untuk menyampaikan informasi terkait diri mereka di dunia nyata. Kemiripan antara jenis informasi yang dibuka dan ditutupi oleh para roleplayer menyiratkan bahwa dibandingkan substansi dari informasi, kepada siapa mereka akan membuka informasi menjadi faktor yang lebih dipertimbangkan. Ini juga didukung oleh waktu yang dihabiskan para roleplayer untuk berinteraksi dengan orang yang mereka anggap dekat dan mereka percayai. Karena roleplay merupakan salah satu bentuk computer-mediated communication (CMC), maka informasi yang dapat ditampilkan oleh komunikator akan lebih terbatas dibandingkan komunikasi tatap muka, sehingga akan membutuhkan waktu yang lebih banyak dalam mencapai kedekatan pribadi dengan seseorang (Walther, 2015). 


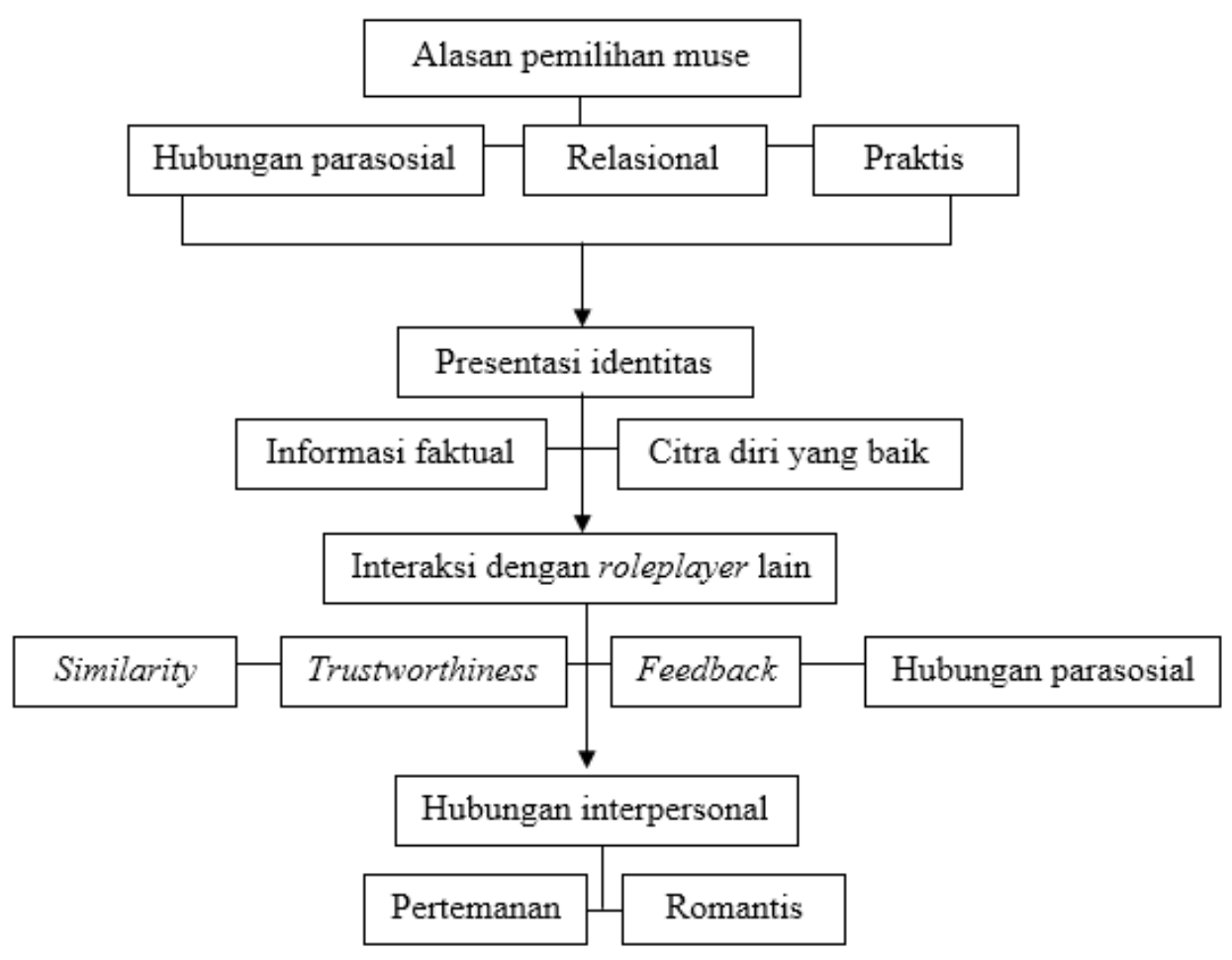

Gambar 11. Bagan presentasi identitas dan hubungan interpersonal di dunia roleplay (dokumentasi pribadi peneliti)

\section{SIMPULAN DAN SARAN}

Penelitian ini bertujuan untuk menjelaskan secara lebih komprehensif tentang konstruksi identitas dan relasi pada dunia roleplay. Data didapatkan dari jawaban kuisioner terbuka kepada 131 pemain roleplay. Berdasarkan teori interaksionisme simbolik yang menuntun penelitian ini, ditemukan bahwa self yang dimaksud dalam dunia roleplay adalah identitas artis K-Pop yang diperankan oleh roleplayer. Identitas ini dikonstruksi melalui bagaimana para mun membentuk interpretasi tertentu mengenai artis tersebut dan difasilitasi lebih lanjut dengan pembangunan hubungan interpersonal dengan sesama roleplayer. Hubungan interpersonal yang menjadi fokus dalam penelitian ini adalah hubungan pertemanan dan hubungan romantis, dan masing-masing memiliki karakter uniknya tersendiri.

Topik mengenai roleplayer sebagai bagian dari budaya partisipatoris dalam fandom K-Pop masih belum banyak diteliti, sehingga penelitian ini hadir untuk mengeksplorasi dasar-dasar dari kegiatan roleplaying itu sendiri. Oleh karena itu, penelitian ini masih terbatas dari sisi generalisasi karena belum adanya data kuantitatif yang dapat membuktikan hipotesis-hipotesis tertentu. Peneliti selanjutnya diharapkan dapat melengkapi celahcelah yang belum dicapai oleh penelitian ini menggunakan data kuantitatif sehingga hubungan atau pengaruh antara masing-masing variabel dapat diketahui secara lebih jelas.

\section{REFERENSI}

Abd-Rahim, A. (2019). Online fandom: social identity and social hierarchy of Hallyu fans. Journal for Undergraduate Ethnography, 65-81.

Alruwaili, T. O. (2017). Self-identity and community through social media: The experience of Saudi female international college students in the United States. Dissertation for University of Northern Colorado.

Antheunis, M. L., Valkenburg, P. M., \& Peter, J. (2010). Getting acquainted through social network sites: Testing a model of online uncertainty reduction and social attraction . Computers in Human Behavior, 100-109.

Baron, R. A., \& Branscombe, N. R. (2012). Social Psychology: 13th Edition. New Jersey: Pearson Education, Inc. Bland, E. (2019). How "Smart" Are K-Pop Fans: Can the Study of Emotional Intelligence Of K-Pop Fans Increase Marketing Potential? Culture and Empathy, 105-115.

Blumer, H. (1986). Symbolic Interactionism: Perspective and Method. California: Univ of California Press. 
Booth, P. (2010). Digital fandom: New media studies. Peter Lang.

Boyd, D., Golder, S., \& Lotan, G. (2010). Tweet, tweet, retweet: Conversational aspects of retweeting on twitter. 43rd Hawaii international conference on system science (pp. 1-10). Hawaii: IEEE.

Braun, V., \& Clarke, V. (2006). Using Thematic Analysis In Psychology. Qualitative Research In Psychology, $77-$ 101.

Buckingham, D. (2008). Introducing identity. In D. John, \& T. Catherine, Youth, Identity, and Digital Media (pp. 1-24). Cambridge: The MIT Press.

Chen, R. R., Davison, R. M., \& Ou, C. X. (2020). A symbolic interactionism perspective of using social media for personal and business communication. International Journal of Information Management, 51.

Colburn, A. (2000). Constructivism: Science education's "grand unifying theory". The Clearing House: A Journal of Educational Strategies, Issues and Ideas, 74(1), 9-12.

Cushman, D. P., \& Cahn, D. D. (1985). Communication in Interpersonal Relationships. SUNY Press.

de Lopes, M. I. (2012). A case study on transmedia reception: Fandom on Facebook and social issues in the Brazilian telenovela Passione. Anàlisi: Quaderns de comunicació i cultura, (monografic), 111-132.

DeMeo, E. (2016). Fandom and Social Media Marketing Looking at" Doctor Who" Tumblr Engagement Through the Lens of Participatory Culture. Thesis for Master of Arts in Strategic Communication Liberty University.

Fatmawati, S., \& Ali, D. S. (2017). Motif Interaksi Sosial Role-player Pada Mahasiswa Universitas Telkom Di Social Networking Twitter. eProceedings of Management, 4(3).

Finkel, E. J., Norton, M. I., Reis, H. T., Ariely, D., Caprariello, P. A., Eastwick, P. W., . . Maniaci, M. R. (2015). When does familiarity promote versus undermine interpersonal attraction? A proposed integrative model from erstwhile adversarie. Perspectives on Psychological Science, 3-19.

Gazzaniga, M., Heatherton, T. F., Halpern, D. F., \& Heine, S. J. (2012). Psychological Science: Third Canadian Edition. New York: W.W. Norton \& Company, Inc.

Gilburt, H., Rose, D., \& Slade, M. (2008). The importance of relationships in mental health care: A qualitative study of service users' experiences of psychiatric hospital admission in the UK. BMC health services research, 92.

Goldstein, B. E. (2011). Cognitive Psychology: Connecting Mind, Research, And Everyday Experience (3rd Edition). Wadsworth: Cengage Learning.

Griffin, E. (2012). A First Look At Communication Theory : 8th Edition. New York: The McGraw-Hill Companies, Inc.

Guschwan, M. (2012). Fandom, brandom and the limits of participatory culture. Journal of Consumer Culture, 19-40.

Hanley, S. (1994). On constructivism. Maryland Collaborative for Teacher Preparation.

Horton, D., \& Wohl, R. R. (1956). Mass communication and Parasocial Interaction: Observations on Intimacy at a Distance. Psychiatry Interpersonal and Biological Processes, 19(3), 215-229.

Jeewa, Z., \& Wade, J. (2015). Playing with identity: Fan role playing on Twitter. Alternation Journal: Interdisciplinary Journal for the Study of the Arts and Humanities in Southern Africa, 216-240.

Jenkins, H. (2006). Convergence Culture : Where Old and New Media Collide. New York: New York University Press.

Jenkins, H. (2006). Fans, bloggers, and gamers: Exploring participatory culture. nyu Press.

Jenkins, H. (2012). Textual poachers: Television fans and participatory culture. Routledge.

Juhasz, A., \& Bradford, K. (2016). Mobile phone use in romantic relationships. Marriage \& Family Review, 707721.

Jung, J., Lee, S., \& Lee, S. (2017). When Indonesians Routinely Consume Korean Pop Culture: Revisiting Jakartan Fans of the Korean Drama Dae Jang Geum. International Journal of Communication , (11) 2288-2307.

Kim, B. R. (2015). Past, Present and Future of Hallyu (Korean Wave). American International Journal of Contemporary Research, 5(5) 154-160.

Kuo, L., Perez-Garcia, S., Burke, L., Yamasaki, V., \& Le, T. (2020). Performance, Fantasy, or Narrative: LGBTQ+ Asian American Identity through Kpop Media and Fandom. Journal of Homosexuality, 1-24.

Kurniawati, D. A. (2015). K-pop dan new media Studi Kasus Produksi dan Penerimaan Pesan antar Roleplayer dalam Twitter di kalangan K-popers Solo. Program Studi IImu Komunikasi Fakultas IImu Sosial dan Ilmu Politik Universitas Sebelas Maret Surakarta.

Lewicki, R. J., Tomlinson, E. C., \& Gillespie, N. (2006). Models of interpersonal trust development: Theoretical approaches, empirical evidence, and future directions. Journal of management, 991-1022.

Lie, J. (2012). What is the K in K-pop? South Korean popular music, the culture industry, and national identity. Korea Observer, 339-363. 
Littlejohn, S. W., Foss, K. A., \& Oetzel, J. G. (2016). Theories of Human Communication: 11th edition. Long Grove: Waveland press.

Madni, G. R. (2014). Consumer's behavior and effectiveness of social media. Global Journal of Management and Business Research: E Marketing, 56-62.

Markham, A. N., \& Lindgren, S. (2014). From object to flow: Network sensibility, symbolic interactionism, and social media. Symbolic interaction and new social media: Emerald Group Publishing Limited, 7-41.

McClellan, A. (2013). A case of identity: Role playing, social media and BBC Sherlock. The Journal of Fandom Studies, 139-157.

McDonald, K. (2017). Radicality and Regulation: Negotiating Selfhoold In Tumblr Roleplay. Doctoral dissertation, Central European University.

Miller, T., Govil, N., McMurria, J., \& Maxwell, R. (2001). Global Hollywood. London: BFI.

Nugraha, R. P. (2020). Establishment of Role-Player as a Virtual Identity in Twitter Social Media. Proceedings of the First Brawijaya International Conference on Social and Political Sciences (B-SPACE). Malang: EAI.

Otolorin, M., \& Spatichia, D. (2017). K-pop Subculture International Impact. Temple Undergraduate Research Prize Winners.

Perse, E. M., \& Rubin, R. B. (1989). Attribution in social and parasocial relationships. Communication Research, 59-77.

Pramadya, T. P., \& Oktaviani, J. (2016). “HALLYU” (KOREAN WAVE) AS PART OF SOUTH KOREA'S CULTURAL DIPLOMACY AND ITS IMPACT ON CULTURAL HYBRIDITY IN INDONESIA. Dinamika Global, 87-117.

Pratiwi, L. P., \& Putra, A. (2018). Motif Sosiogenesis Pasangan Roleplay Dalam Media Sosial Twitter. Jurnal Manajemen Komunikasi, 127-143.

Sneed, J. R., \& Whitbourne, S. K. (2003). Identity Processing and Self-Consciousness in Middle and Later Adulthood. The Journals of Gerontology: Series B, Volume 58, Issue 6, 313-319.

Stever, G. S. (2017). Evolutionary theory and reactions to mass media: Understanding parasocial attachment. Psychology of Popular Media Culture, 95-102.

Sue, V. M., \& Ritter, L. A. (2007). Conducting Online Surveys. California: Sage Publications, Inc.

Tantra, G. G. (2020). Defending K-pop Idols Online: The Fanbase's Underlying Issue of Ignorance. Pop Culture Intersections.

Thorne, S., \& Bruner, G. C. (2006). An exploratory investigation of the characteristics of consumer fanaticism. Qualitative Market Research: An International Journal, 51-72.

Turner, G. (2013). Understanding Celebrity. Sage.

Walther, J. B. (2015). Social information processing theory (CMC). The international encyclopedia of interpersonal communication, 1-13.

West, R., \& Turner, L. H. (2010). Introducing Communication Theory: Analysis and Application. New York: McGraw Hill.

Wong, W. K. (2012). Faces on Facebook: A study of self-presentation and social support on Facebook (Outstanding Academic Papers by Students (OAPS)). Retrieved from City University of Hong Kong, CityU Institutional Repository: http://hdl.handle.net/2031/6847

Yan, Q., \& Yang, F. (2020). From parasocial to parakin: Co-creating idols on social media. New Media \& Society, $1-23$. 